\title{
THE LEGALITY OF HYBRID CONTRACT ON SBSN (SUKUK) IJARAH SALE AND LEASE BACK IN DSN-MUI FATWA
}

\author{
Panji Adam ${ }^{1}$, Redi Hadiyanto ${ }^{2}$, Indra Wijaya ${ }^{3}$, Dina Rahmania ${ }^{4}$ \\ Fakultas Syariah Universitas Islam Bandung \\ Jl. Tamansari No. 24-26 Bandung \\ panjiadam06@gmail.com ${ }^{1}$, redihadiyanto@gmail.com², \\ indrawijayaiii76@gmail.com ${ }^{3}$, dinarahmania04@gmail.com ${ }^{4}$
}

Received: 2 August 2020; Revised: 10 Juli 2020; Published: 31 Desember 2020

\begin{abstract}
ABSTRAK
Berkembangnya industri keuangan syariah turut mendorong lahirnya pasar modal syariah beserta variasi jenis instrumen yang tersedia. Salah satu instrumen pasar modal syariah yang saat ini berkembang pesat adalah sukuk. Dewan Syariah Nasional-Majelis Ulama Indonesia telah mengeluarkan fatwa mengenai sukuk, yaitu Fatwa Nomor 72 Tahun 2008 tentang SBSN Ijarah Sale and Lease Back. Konsep mengenai sukuk dalam Fatwa DSN-MUI menggunakan konsep multi akad. Hal ini melahirkan perbedaan pendapat para ahli mengenai status hukum fatwa DSN yang menggunakan multi akad dalam SBSN Ijarah Sale and Lease Back. Metode penelitian yang digunakan adalah yuridis normatif. Sedangkan jenis penelitian ini adalah deskriptif analisis dan teknik pengumpulan data adalah studi pustaka metode analisis data adalah kualitatif. Hasil penelitian menunjukan bahwa; pertama, takyif figh dalam skema SBSN menggunakan akad al-bai' wa al-isti'jar yaitu gabungan antara akad bai' dan akad ijârah; kedua, konsep multi akad dalam Fatwa DSN-MUI No. 72 tentang SBSN Ijarah Salse and Lease Back merupakan multi akad yang diperbolehkan secara syariah.
\end{abstract}

Kata Kunci: Sukuk, Multi Akad, Fatwa DSN-MUI

\section{ABSTRACT}

The National Sharia Council-Indonesian Ulema Council has issued a fatwa regarding sukuk, namely Fatwa Number 72 of 2008 concerning SBSN Ijarah Sale and Lease Back. The concept of sukuk in the DSN-MUI Fatwa uses the concept of hyrid contracts. This has resulted in differences of opinion from experts regarding the legal status of the DSN fatwa using the multi-agreement in the SBSN Ijarah Sale and Lease Back. The research method used is normative juridical. While the type of this research is descriptive analysis and the data collection technique is literature study. The data analysis method is qualitative. The results showed that; first, takyif figh in the SBSN scheme uses the al-bai 'wa al-isti' jar contract, which is a combination of the bai' contract and the ijârah contract; second, the hybrid contract concept in the DSN-MUI Fatwa No. 72 regarding SBSN Ijarah Salse and Lease Back is a hybrid contract agreement that does not violate the rules and boundaries of the hybrid contract theory that have been formulated by the scholars.

Key Words: Sukuk, Multi Akad, Fatwa DSN-MUI 


\section{PENDAHULUAN}

Salah satu instrumen syariah yang tumbuh pesat adalah sukuk. Instrumen ini menjadi jembatan penghubung (intermediary) antara pemilik modal dengan pengguna modal. Pemilik modal menjadikan sukuk sebagai sarana investasi sedangkan pengguna modal menjadikan sukuk sebagai sarana untuk memperoleh pembaiyaan. Keduanya selanjutnya mengadakan perikatan untuk melaksanakan suatu jenis transaksi yang menghasilkan barang atau jasa tertentu. Perikatan antara kedua belah pihak tersebut dalam konteks fikih muamalah disebut sebagai akad (perikatan). Jenis penggunaan akad yang digunakan sangat dipengaruhi oleh jenis barang dan atau jasa yang ditransaksikan. Barang atau jasa yang dijadikan sebagai objek transaksi selanjutnya disebut sebagai underlying aset (Eri Hariyanto, 2017).

Melihat perkembangan sukuk di negara-negara lain, serta pengalaman yang terjadi selama ini, terutama dari segi manfaat yang ditimbulkannya, pemerintah marasa berkepentingan untuk mengeluarkan regulasi yang dapat mendukung perkembangan sukuk di dalam negeri. Sebagai tindak lanjut, penerapan sukuk diwujudkan ke dalam bentuk penerbitan Surat Berharga Syariah Negara (SBSN). Tujuan penerbitan SBSN adalah dalam rangka mencari alternatif sumber pembiayaan negara, di mana ketentuannya diatur dalam Undang-Undang SBSN Nomor 19 Tahun 2008 (Burhanuddin, 2011).

Dewan Syariah Nasional Majelis Ulama Indonesia (DSN-MUI) sebagai lembaga yang memiliki kewenangan mengeluarkan fatwa yang berkaitan dengan lembaga ekonomi dan keuangan syariah teah mengeluarkan fatwa tentang sukuk, yaitu Fatwa DSN-MUI Nomor 72 Tahun 2008 tentang SBSN Ijarah Sale and Lease Back.

Sukuk Ijarah Sale and Lease Back ini merupakan sukuk yang berbasis pada konsep multi akad (al-'uqûd al-murakkabah). Sukuk ini menggabungkan akad ijârah (sewa-menyewa) dengan akad jual-beli (bai'). Pertama, investor (pembeli) melalui wakilnya dan emiten (pemilik, penjual aset dan penerbit sukuk) melakukan akad jual-beli aset yang menjadi dasar penebitan sukuk. Kedua, emiten berjanji kepada investor bahwa pada akhir periode sukuk, aset akan dibeli kembali oleh emiten. Uang investor untuk pembelian aset berasal dari penerbitan sukuk. Demikian, selama periode penerbiatan (umur) sukuk kepemilikan aset berpindah tangan dari emiten kepada investor. Setelah itu, investpr dan emiten melakukan akad sewa-menyewa (ijârah) atas aset tersebut. Investor sebagai pemilik aset yang sekaligus pembeli sewa ( $\left.m u^{\prime} j i r\right)$ dab eniten sebagai pihak penyewa (musta'jir). Investor akan menerima fee (ujrah) dar emiten 
sebaai pembayaran jasa sewa aset. Ujrah yang dibayar emiten akan dikonverso menjadi keuntungan investor (Abdalloh, 2018).

Konsep multi akad yang digunakan dalam perjanjian SBSB/sukuk ijarah sale and lease back dala Fatwa DSN-MUI Nomor 72 terdiri atas akad jual-beli (bai'), sewa-menyewa (ijârah) dan janji (wa'ad) untuk menjual/membeli kembali. Sementara dalam kacamata fikih muamalah kontemporer, kontrak/perjanjian ini masih memerlukan kajian lebih lanjut karena ulama salaf dalam kitab-kitab fikih klasik yang mu'tabar belum membahas mengenai konsep penggabungan akad seperti ini (N. A. Wahid, 2017). Demikian, perlu dilakukan pengkajian serta penelitian berkaitan dengan keabasahan multi akad dalam SBSN Ijarah Sale and Lease Back dalam Fatwa DSN-MUI Nomor 72 Tahun 2008.

\section{Konsep Multi Akad (al-'uqûd al-murakkabah)}

Multi dalam bahasa Indonesia berarti banyak; lebih dari satu; lebih dari dua; berlipat ganda. Sedangkan akad berasal dari bahasa Arab al-'aqd yang berarti secara etimologi berarti perikatan, perjanjian, dan permufakatan (alittifâq). Secara terminologi fikih, akad ialah ikatan (pertalian) antara ijab (pernyataan melakukan ikatan) dan kabul (pernyatan penerimaan ikatan) sesuai dengan kehendak syariat yang berimplikasi kepada objek perikatan. Dengan demikian, multi akad dalam bahasa Indonesia berarti akad berganda atau akad yang banyak, lebih dari satu (N. Wahid, 2019).

Dalam buku-buku teks fikih muamalah kontemporer istilah multi akad atau hybrid contract disebutkan dengan beragam istilah, antara lain al-'uqûd almurakkabah (akad-akad yang bersusun), al-'uqûd al-muta'adiddah (akad-akad yang berbilang), al-'uqûd al-mutaqâbilah (akad-akad yang berpasangan), al-'uqûd almujtami'ah (akad-akad yang berhimpun), al-'uqûd al-mukhtalitah (akad-akad yang bercampur), al-'uqûd al-mutakarrirah (akad-akad yang berulang), dan al-'uqûd almutadakhilah (akad yang satu masuk kepada akad yang lain). Namun istilah yang paling popular ada 2 (dua) macam, yaitu al-'uqûd al-murakkabah dan al-'uqûd almujtami'ah, dan ada pula yang menggunakan istilah al-'uqûd al-mutajanisah (akad-akad yang sejenis).

Dalam khazanah fikih muamalah kontemporer, kata multi akad atau hybrid contract merupakan terjemah dari kata al-'uqûd al-murakkabah. Kata murakkab sendiri berasal dari kata rakkaba-yurakkibu-tarkiban yang mengandung arti meletakkan sesuatu pada sesuatu yang lain sehingga menumpuk, ada yang di atas dan yang di bawah. Sedangkan murakkab menurut pengertian para ulama fikih adalah: pertama, himpunan beberapa hal sehingga disebut dengan satu nama. Seseorang menjadikan beberapa hal menjadi satu hal (satu nama) 
dikatakan sebagai melakukan penggabungan (tarkîb). kedua, sesuatu yang dibuat dari dua atau beberapa bagian, sebagai kebalikan dari sesuatu yang sederhana (tunggal/ basith) yang tidak memiliki bagian-bagian. ketiga, meletakkan sesuatu di atas sesuatu lain atau menggabungkan sesuatu dengan yang lainnya (Fathoni, 2018).

Secara terminologi fikih muamalah kontemporer, para ulama merumuskan definisi mengenai multi akad atau hybrid contract adalah sebagai berikut:

Nazih Hammad sebagaimana dikutip oleh Ali Ibn Husain al-Aidi mendefinisikan hybrid contract atau multi akad sebagai beirkut:

"Kesepakatan dua pihak untuk melaksanakan suatu akad yang mengandung dua akad atau lebih --seperti jual beli dengan sewa menyewa, hibah, wakalah, qardh, muzara'ah, sahraf (penukaran mata uang), syirkah, mudharabah ... dst.-- sehingga semua akibat hukum akad-akad yang terhimpun tersebut, serta semua hak dan kewajiban yang ditimbulkannya dipandang sebagai satu kesatuan yang tidak dapat dipisah-pisahkan, sebagaimana akibat hukum dari satu akad."(Al-Aidi, 2012)

Lebih lenjut Al-Aidi mengutip pendapat Abdullah al-'Imrani dalam kitabnya yang berjudul "al-'Uqûd al-Mâliyyah al-Murakkabah: Dirâsah Fiqhiyyah Ta'shilliyyah wa Tahtbîqiyyah" memberikan denfinisi multi akad/hybrid contract sebagai berikut:

""Himpunan beberapa akad kebendaan yang dikandung oleh sebuah akad, baik secara gabungan maupun secara timbal balik-sehingga seluruh hak dan kewajiban yang ditimbulkannya dipandang sebagai akibat hukum dari satu akad." (Al-Aidi, 2012)

Kedua definisi di atas tampaknya mirip dan tidak terdapat perbdaan. Multi akad itu dipandang sebagai satu kesatuan dan semua akibat hukum akadakad yang tergabung tersebut, serta semua hak dan kewajiban yang ditimbulkan dipandang sebagai satu kesatan yang tidak dpaat dipisah-pisahkan, sebagaimana akibat hukum dari satu akad. Menurut al-Syathibi sebagaimana dikutip oleh Agustianto Mingka, penelitian terhadap hukum Islam meunjukan bahwa dampak hukum dari multi akad tidak sama seperti saat akad itu berdiri sendiri-sendiri (Mingka, 2014).

Dalam praktik multi akad, para ulama telah memberikan batasan-batasan yang sudah disepakati agar multi akad tidak melanggar ketentuan syariah. Adapun praktik multi akad yang melanggar kaidah-kaidah adalah sebagai berikut: (1) multi akad dilarang karena nash agama; (2) multi akad sebagai hilah (rekayasa) praktik riba; (3) multi akad berimplikasi jatuhnya ke dalam praktik 
ribawi; dan multi akad terdiri dari akad-akad yang akibat hukumnya saling bertolak belakang atau berlawanan (Maulana, 2011) .

\section{Konsep Sukuk Ijarah Sale and Lease Back}

Istilah sukuk (صكوك) adalah bentuk plural atau jamak dari kata sakk (صك)) yang merupakan istilah dari Bahasa Arab yang memiliki makna sertifikat. Definisi lain menjelaskan bahwa kata sakk, bentuk jamak-nya adalah "sukuk" atau "sakik", yang berarti memukul atau membentur, dan juga bisa bermakna "pencetakan atau menempa" sehingga apabila dikatakan "sakkan nuqud" maknanya adalah "pencetakan atau penempahan uang" (Manzhur, 2013).

Dalam konteks hukum dan regulasi di Indonesia istilah sukuk dikenal dengan sebutan Surat Berharga Syariah Negara. Pasal 1 angka 1 UndangUndang Nomor 19 Tahun 2009 tentang Surat Berharga Syariah Negara (SBSN) didefinisikan bahwa:

"Surat Berharga Syariah Negara (SBSN) atau sukuk negara (sovereign sukuk) adalah surat berharga negara yang diterbitkan berdasarkan prinsip syariah yang berfungsi sebagai alat bukti atas bagian penyertaan terhadap aset SBSN, baik dalam bentuk mata uang rupiah maupun valas (valuta asing).

Definisi tersebut menunjukan bahwa kepemilikan sukuk bersifat undivided shares (tidak dapat dibagi) baik dalam kepemilikan aset yang bersifat tangible, manfaat dan pelayanan atau kepemilikan atas aset tertentu yang berada daam proses investasi. Sehingga, meskipun sukuk dimiliki oleh banyak investor (sukuk holder), kepemilikan atas sukuk tersebut dibagi. Misalkan saja, jika penerbitan sukuk dengan melakukan proses investasi atas aset tertenu, maka akses atas kepemilikan aset tersebut tidak dapat dibagi sesuai dengan besaran kepemilikan investor (Fakhrunnas, 2019).

Struktur sukuk Ijarah Sale and Lease Back dapat digunakan dalam rangka memperoleh dana yang akan digunakan untuk tujuan umum (general financing purpose) melalui proses monetiasi aset yang dimiliki oleh originator. Proses tersebut dilakukan dengan cara penjualan aset kepada investor untuk kemudian disewakan kembali kepada oroginator, dan pada saat jatuh tempo aset tersebut akan dibeli kembali.

Sale and Lease Back dapat diartikan sebagai transaksi dengan menggunakan akad bai' (jual-beli) aset dimana pihak pembeli kemudian menyewakan kembali aset yang telah dibelinya kepada pihak penjual. Fatwa DSN-MUI Nomor 71/DSN-MUI/VI/2008 tentang Sale and Lease Back menyatakan mengenai kebolehan akad tersebut. Akad yang digunakan dalam skema sukuk Ijarah Sele and Lease Back adalah akad bai' (jual-beli) dan akad ijârah 
(sewa-menyewa) yang keduanya dilaksanakan secara terpisah. Sukuk negara yang menggunakan skema Sele and Lease Back dinamakan SBSN Ijarah Sele and Lease Back, dan Fatwa DSN-MUI No. 72/DSN-MUI/VI/2008 memberikan landasan serta pedoman syariah bagi penerbitan SBSN yang menggunakan struktur tersebut.

Berdasarkan fatwa DSN-MUI No. 71/2008 tengang Sale and Lease Back, aset yang dapat dipergunakan sebagai objek pada akad ijârah (sewa-menyewa) dalam transaksi Sale and Lease Back adalah barang yang memiliki manfaat dan nilai ekonomis. Dengan demikian, underlying asset dalam penerbitan SBSN Ijarah Sale and Lease Back menggunakan aset milik negara yang berupa Barang Milik Negara (BMN). BMN yang digunakan dalam penerbitan Sukuk Negara adalah dapat dalam bentuk tanah dan/atau bangunan yang tersebar di berbagai Kementrian/Lembaga di seluruh Indonesia. Penggunaan BMN sebagai objek/underlying asset pada Sukuk Negara diatur lebih lanjut dalam PMK No. 04/PMK/08/2009 tentang Pengelolaan Aset SBSB yang Berasal dari Barang Milik Negara.

\section{METODE PENELITIAN}

Metode penelitian yang digunakan dalam penelitian ini adalah normative legal studies, yaitu metode yang digunakan untuk meneliti objek berdasarkan norma hukum. Dalam kajian fikih muamalah, norma hukum yang berlaku adalah norma hukum dan asas fikih muamalah. Dengan demikian, penelitian ini berangkat dari studi pustaka dengan menggunakan bahan-bahan sekunder. Sumber utama dalam penelitian ini adalah Fatwa Dewan Syariah NasionalMajelis Ulama Indonesia (DSN-MUI No. 71 Tahun 2008 tentang Sale and Lease Back dan Fatwa fatwa No. 72 Tahun 2008 tentang Surat Berharga Syariah Negara Ijarah Sale and Lease Back. Sumber sekunder dalam penelitian ini adalah kitabkitab fikih muamalah baik klasik maupun kontemporer yang relevan dengan fokus penelitian ini. Teknik pengumpulan data dalam penelitian ini dilakukan dengan cara studi pustaka, yaitu dengan cara menelaah kitab-kitab muamalah dan fatwa DSN-MUI yang berkaitan dengan fokus penelitian. Adapun metode analisis data yang digunakan dalam penelitian ini adalah metode kualitatif. 


\section{HASIL PENELITIAN DAN PEMBAHASAN}

\section{Takyif Fikih Skema Transaksi SBSN Ijarah Salse and Lease Back}

Konsep sale and lease back merupakan istilah yang digunakan dalam hukum bisnis. Sale and Lease Back adalah suatu jenis pembiayaan yang barang sebenarnya berasal dari lessee, kemudian dibeli oleh lessor. Kemudian, barang tersebut yang sudah berada ditangan lessor disewakan kembali kepada lessee berdasarkan periode waktu tertentu yang disepakati. Dalam konsep Sale and Lease Back biasanya digunakan skema financial lease dimana pihak lessor dari awal tidak berkehendak untuk memiliki barang yersebut sehingga bentuk Sale and Lease Back ini hampir mirip dengan utag uang untuk suatu keperluan tertentu dengan pembayaran secara cicil, dimana posisi barang/objek tersebut diperguanakan sebagai jaminan utang (Fuady, 2002).

Dalam hukum Islam, khususnya ketika membahas akad bai' (jual-beli) terdapat istilah bai' al-haqîqî (jual-beli yang sesuangguhnya) dan bai' al-shûrî (jualbeli dalam artifisial). Implikasi hukum dalam akad jual-beli yang sesungguhnya (bai' al-haqîii) adalah terjadinya intiqâl al-milkiyyah (perpindahan kepemilikan). Oleh sebab itu, ketika terjadi perjanjian jual-beli ('aqd al-bai') yang tidak berimpikasi adanya perpindahan kepemilikan merupakan bentuk jual-beli artifisial (bai' al-shûrî) yang qarinah-nya (indikator) dapat berupa dokumen dan/atau penguasaannya, baik secara nyata maupun secara hukum ( $q a b d h$ ), setelah terjadi serah terima barang (taslim al-mabî') (Hasanuddin, 2015).

Diskusi mengenai konsep Sale and Lease Back secara tidak langsung berkaitan dengan kosep jual-beli wafa (bai' al-wafâ). Secara etimologis definisi al$b a^{\prime}$ adalah jual beli. Adapun wafa menurut bahasa berarti ضد الغر (kebalikan dari khianat atau ingkar janji). Dengan demikian الوفاء (wafa) artinya yaitu memenuhi janji. Akad tersebut dinamakan bai' al-wafa, karena adanya keharusan si pembeli menetapi janjinya yang telah disepakatinya dengan penjual, yaitu menjual kembali barang yang telah dibelinya kepada pemilik asal (penjual pertama).

Adapun definisi bai' al-wafa secara terminologi sebagaimana dikemukakan dalam kitab Majallat al-Ahkkâm al-'Adliyyah Pasal 118, yaitu:

"Jual beli dengan syarat si penjual dapat membeli kembali barang yang telah dijualnya kepada pembeli pada waktu yang telah disepakati bersama"(Anonimous, n.d.).

Definisi lain dari Musthafa Ahmad Zarqa bahwa yang dimaksud dengan bai' al-wafâ adalah: 
"Seseorang menjual harta 'aqâr (benda tidak bergerak) yang dilakukan secara tunai, kemudian pada waktu yang telah ditentukan dia (penjual) membeli kembali (dari pembeli) dengan harga yang sama ketika ia jual" (Musthafa Ahmad al-Zarqa, 1999).

Apabila ditelaah, maksud dari transksi dengan skema bai' al-wafâ adalah untuk memberikan pinjam serta mengambil keuntungan yang diperbolehkan secara syariah serta memberikan kesempatan bagi debitur untuk memanfaatkan barang yang telah ia jual serta keinginan untuk memilikinya kembali barang tersebut. Sejak awal Akad jual-beli wafâ dibangun berdasarkan akad bai' (jualbeli), dengan demikian pihak pembeli diberikan kebebasan untuk memanfaatkan barang yang telah dibelinya. Akan tetapi terdapat kesepakatan (antara penjual dan pembeli) bahwa tersebut tidak diperbolehkan dijual kepada pihak ketiga/orang lain, artinya pihak pembeli hanya diperbolehkan untuk menjual kembali kepada pihak penjual. Karena objek/barang tersebut pada hakikatnya merupakan jaminan atas hutang yang wajib untuk dikenbalikan sesuai dengan waktu yang disepakati. Apabila pihak debitur telah membayar utang-nya maka kreditur wajib mengembalikan barang tersebut (Suhardi, 2019). Praktik seperti ini secara substansi mirip dengan utang disertai jaminan atau dalam istilah sederhana disebut dengan gadai.

Bai al-wafâ pertama kali muncul di Balkh dan Bukahri pada akhir abad ke5 Hijriyyah. Akad bai' al-wafâ memiliki beberapa nama, yaitu ulama Malikiyyah menamainya dengan bai' al-tsunayâ (jual-beli ulang); ulama Syafi'iyyah menamainya dengan bai' al-'uddah (jual-beli janji); ulama Hanabilah menamainya dengan bai' al-amânah (jual-beli kepercayaan); di Mesir dikenal dengan istilah bai' al-ma'âd; di Syam perspektif ulama Hanafiyyah disebut dengan bai' al-ithâ'ah; bai' an-âs dan bai' al-mu'âmalah (Thalib ‘Umar Ahmad al-Katsiri, 2015).

Apabila dilihat dari aspek sosio-historis, sistem jual-beli wafâ ini muncul dikalangan masyarakat Bukhara dan Balkh pada abad ke-5 Hijriah sebagaimana disinggung di atas dilatarbelakangi oleh banyak pihak yang memiliki uang akan tetapi mereka tidak berkenan untuk memberikan uang tersebut kepada orang yang membutuhkan uang tanpa adanya kompensasi, dan hal ini berdampak kepada kesulitan bagi orang yang membutuhkan uang. Dengan demikian muncullah sebuah skema akad yang mereka buat agar kebutuhan masyarakat yang membutuhkan uang terpenuhi dan pemilik uang pun merasa aman sehingga dibuatlah akad bai' al-wafâ. Oleh karana itu, jual-beli wafâ menjadi solusi bagi kedua belah pihak, satu pihak masyarakat yang membutuhkan uang terpenuhi kebutuhannya, pada saat yang sama mereka pun dapat terhidar dari transaksi ribawi (Ubaidillah \& Nawawi, 2017). 
Skema transaksi dengan menggunakan konsep bai' al-wafâ perlu diteliti apakah dasar pertimbangan hukum dari para fukaha ketika itu didasarkan pada 'urf (kebiasaan) yang sudah terbiasa dilakukan pada saat itu, atau terdapat pertimbangan lain, yaitu pertimbangan berdasarkan nilai kemanfaatan hukum atau mashlahah (Yanti, 2017).

Apabila ditelaah, jual-beli wafâ maka ada 3 (tiga) bentuk skema transaksi didalamnya, yaitu: (1) ketika dilangsungkannya transaksi, akad ini merupakan akad bai' (jual-beli), karena nomenklatur akad ini adalah akad bai' (jual-beli); (2) karena ini merupakan akad jual-beli, maka berimplikasi terhadap perpindahan kepemilikan barang dari penjual kepada pembeli, akan tetapi dalam jangka waktu yang telah disepakati objek/barang tersebut berpindah kembali kepada penjual, maka terlihat seakan transaksi ini mirip dengan akad ijârah (sewamenyewa), yaitu kepemilikan atas suatu manfaat barang yang diperbolehkan oleh syariat selama waktu tertentu yang disepakati disertai adanya kompensasi; (3) ketika jual-beli wafâ sudah jatuh tempo, maka pihak penjual harus mengembalikan harga (uang) kepada pembeli sejumlah harga pembelian di awal, dan pembeli harus mengembalikan barang kepada penjual (Sri Sudiarti, 2016).

Akad jual-beli wafâ merupakan perjanjian yang populer dalam mazhab Hanafi. Akad jual-beli wafâ secara substansi merupakan perpaduan antara akad jual-beli (bai') dengan akad gadi ( $r a h n)$. Akad ini dibolehkan oleh ulana Hanafiyyah dan beberapa negara mengakui keabsahannya serta membuat aturan khusus dalam qânûn (undang-undang) perdata, seperti Turki Usmani, akan tetapi mayoritas (jumhur) ulama tidak membolehkan akad tersbebut (Melati Anjaswati, Rohimah, 2016).

Arumentasi lain yang dikemukakan oleh ulama Hanafiyyah adalah bahwa bai' al-wafâ merupakan bentuk akad yang memiliki ciri dan karakteristik khusus yang dibenarkan secara syariah karena terdapat kebutuhan (al-hâajah). Dengan demikian, bai' al-wafâ tidak termasuk akad jual-beli yang sah juga dan tidak termasuk jual-beli yang fasid (rusak), bukan juga perjanjian gadai (rahn), akan tetapi perjanjian atau 'uqûd al-mustahdastah (akad baru) yang memiliki ciri dan karakteristik tertentu (Jaih Mubarok dan Hasanudin, 2017).

Ulama Hanafiyyah kontemporer menghindari perbedatan tentang substansi akad bai' al-wafâ. Menurutnya, akad jual-beli wafâ merupakan sebuah perjanjian tidak bernama ('aqd ghair musamma). Karenannya, perlu adanya ketentuan khusus yang berbeda dengan ketentuan umum dalam akad jual-beli. 
Mayoritas (jumhur) ulama fikih (diantaranya Malikiyyah, Syafi'iyyah dan Hanabilah) berpendapat bahwa bai' al-wafâ termasuk jual-beli yang fasid (rusak). Mereka berargumen bahwa dalam akad jual-beli wafâ terdapat persyaratan penjual membeli kembali barang yang telah ia jual kepada pembeli, dengan demikian skema transaksi ini menyalahi ketentuan dan hakikat dari akad jualbeli (adanya perpindahan kepemilikan). Dalam bai' al-wafâ pihak pembeli dalam memanfaatkan barang yang ia beli dibatasi waktu. Dengan kata lain perpindahan kepemilikan ridak bersifat abadi, sedangkan dalam akad jual-beli seharusnya perpindahan kepemilikan itu tidak dibatasi waktu dan bersifat abadi (Enang Hidayat, 2016).

Lebih lanjut mayoritas ulama berpendapat bahwa akad jual-beli wafâ merupakan akad qardh (hutang-piutang) yang menarik manfaat, dan ia termasuk hilah (rekayasa) transaksi riba, oleh karena itu jumhur memandang sebagai akad/perjanjian yang tidak sah dan tidak diperbolehkan secara syariah karena terdapat hadis Nabi Saw yang melarang bai' al-tsunayâa (salah satu nama bai' alwafâ, yaitu terjadinya dua jual-beli atas satu barang karena janji (wa'ad) (Wahbah al-Zuhaili, 2002).

Dalam konteks hukum di Indonesia, bai' al-wafâ mendapatkan payung hukum dengan adanya Peraturan Mahkamah Agung Republik Indonesia (PERMA) No. 2 Tahun 2008 tentang Kompilasi Hukum Ekonomi Syariah (KHES). Ketentuan mengenai bai' al-wafâ diatur secara khusus dalam Buku II Pasal 112-115.

Konsep salse and lease back merupakan salah satu varian dari konsep leasing. Dalam kajian fikih muamalah, konsep leasing biasanya berkaitan erat dengan konsep Ijârah Muntahiyyah bi al-Tamlik (IMBT). Sedangkan konsep sale and lease bacak dalam kajian fikih muamalah kontemporer biasa disebut dengan istilah al-bai' wa al-isti'jâr.

Subtsnasi bai' wa al-isti'jâr mirip dengan bai' al-istighlâl yang terdapat dalam kitab Majallah al-Ahkâm al-'Adliyyah (Hukum Perdata Islam) Pasal 119 Qanun Turki 1876 H. Dalam Pasal 119 tesebut bai al-istighlâl didefinisikan sebagai berikut:

"Bai' al-istighlâl adalah jual-beli wafâ yang mana pembeli menyewakan kembali barang yang dibelinya kepada penjual".

Jual-beli istighâl pada prinsipnya merupakan hubungan konsep jual-beli wafâ dengan konsep ijârah (sewa-menyewa), yakni pemanfaatan objek-jual beli dengan cara disewa atau disewakan. Dengan kata lain, barang yang sudah dijual kepada pembeli, diseakan kembali oleh pembeli kepada penjual. 
Dalam perspektif mazhab ㅍanafi, akad bai' al-istighlâl merupakan akad yang sah dan diperbolehkan. Adapun menurut Rafiq Yunus al-Mishri akad bai' al-istighlâl merupakan akad yang terlarang. Rafiq Yunus al-Mishri menyatakan bahwa:

"Jual-beli istighlâl mirip dengan bai' al-wafâ, akan tetapi (perbedaannya) adalah muqtaridh (debitur dalam akad qardh/utang-piutang (penjual pada akad jual-beli pertama) menyewa barang yang dijualnya dari muqridh (kreditur dalam akad qardh (pembeli pada akad jual-beli pertama); maka jual-beli istighlâl termasuk akad jual-beli shûry (artifisial) karena tujuan pembeli (dalam akad jual-beli pertama) adalah untuk mencarii profit (transaksi riba) dengan cara sewa (Rafiq Yunus al-Mishri, 2009)"

\section{Analisis Keabsahan Multi Akad pada Sukuk Ijarah Sale and Lease Back dalam Fatwa DSN-MUI}

Perjanjian Sale and Lease Back termasuk perjanjian multi akad (al-'uqûd almurakkabah), dimana terdapat kriteria khusus untuk menyatakan boleh-tidaknya multi akad. Akad-akad yang digunakan dalam Sale and Lease Back diwali dengan perjanjian/akad jual-beli (bai'), kemudian setelah terjadi akad jual-beli antara penjual dan pembeli, kemudian diikuti dengan akad ijârah (sewa-menyewa) dimana barang yang sudah dijual oleh penjual kepada pembeli disewakan ulang oleh pembeli kepada penjual berdasarkan waktu yang disepakati. Setelah itu, terdapat $w a^{\prime} a d$ (janji) bahwa setelah selesai perjanjian sewa-menyewa, pihak pembeli akan menjual kembali barang tersebut kepada penjual. Dengan demikian terlihat ada beberapa akad dalam perjanjian sale and lease back, yaitu akad jual-beli (bai'), akad sewa-menyewa (ijârah) dan janji untuk menjual/membeli kembali ( $\left.w a^{\prime} a d\right)$.

Dalam definisi salse and lease back dalam Fatwa DSN-MUI No. 71 Tahun 2008 tidak terlihat adanya janji, seolah-olah akad jual-beli dan akad sewa terjadi secara alamiah (tanpa direncakan). Padahal, perjanjian sale and lease back pada umumnya dilakukan pihak-pihak dengan skema jual-beli dengan janji dari pihak penjual untuk menyewakan (atau janji dari piihak pembeli untuk menyewakannya kepada penjual) dan pelaksanaan janji, yaitu sewa barang yang sebelumnya diperjualbelikan pihak-pihak. akan tetapi, keberadaan janji dalam perjanjian sale and lease bacak diatur dalam ketentuan khusus (Hasanuddin, 2015).

Perjanjian salse and lease back dalam Sukuk yang terdapat dalam Fatwa DSN-MUI No. 72 Tahun 2008 perlu dianalisis mengenai keabsahan multi akad di dalamnya. Menurut Erwandi Tarmizi, sukuk dengan menggunakan multi 
akad sebagaimana disinggung di atas, yaitu penggabungan antara akad jual-beli (bai'), sewa-menyewa (ijârah) dan janji ( $\left.w a^{\prime} a d\right)$ adalah praktik multi akad yang dilarang, karena menurutnya, sukuk ini sama dengan sukuk ijarah yang diterbitkan oleh Bahrain. Argumentasi yang dikemukakan oleh Erwandi Tarmizi adalah bahwa tidak semua gabungan dari akad yang satuannya mubah hukum gabungannya juga mubah. Beliau memberikan contoh sebagai berikut:

“Menikahi seorang wanita hukumnya adalah mubah, akan tetapi apabila seorang laki-laki menggabungkan untuk menikahi seorang wanita dengan saudari wanitanya maka gabungan dua akad nikah ini menjadi tidak boleh. Begitu juga dengan muamalah maliyah, seperti: akad 'inah yang merupakan gabungan dua akad jual-beli yang satuannya adalah mubah, namun ketika dua akad tersebut digabung dan menjadi sarana untuk terjadinya riba maka mayoritas para ulama mengharamkannya, begitu juga menggabungkan akad pinjaman dan akad jual-beli telah diharamkan oleh Rasulullah Saw, padahal satuan dari masing-masing akad ini dibolehkan" (Erwandi Tarmizi, 2020).

Lebih lanjut, Erwandi Tirmidzi berpendapat bahwa multi akad dalam sukuk ini serupa dengan jual-beli wafấ'. Mengutip pendapat Ibn Taimiyah, maka menurut Erwandi Tarmizi, akad bai' al-wafâ merupakan transaksi jual-beli yang dilarang.

Lebih lanjut, Erwandi Tarmizi berpendapat bahwa akad yang dibuat dalam skema sukuk adalah fiktif dan dijadikan sebagai sarana untuk pengelabuan riba. Dengan demikian dapat disimpulkan menurut pendapat Erwandi Tarmizi bahwa, praktik fatwa DSN-MUI tentang skemas sukuk tidak jauh berbeda dengan skema yang diterapkan oleh Bahrain dalam penerbitan sukuknya. Dengan demikian, hukum sukuk ritel yang diterbitkan oleh pemerintah Indonesia juga tidak akan berbeda dengan hukum Sukuk Bahrain (Erwandi Tarmizi, 2020).

Penulis berpendapat bahwa praktik multi akad dalam SBSN/Sukuk Sale and Lease Back merupakan praktik multi akad yang diperbolehkan. Hal ini berdasarkan kaidah/prinsip dalam melakukan transaksi muamalah adalah boleh. Kaidah tersebut sebagaimana dikemukakan oleh Ibn Tamiyyah sebagai berikut:

"Pada prinsipnya hukum dalam akad dan syarat adalah boleh dan sah, tidak ada yang mengharamkan dan membatalkan kecuali adanya dalil syara atas pengharaman dan pembatalan tersebut, tidak pula adanya nash dan qiyas yang mengharamkan dan membatalkannya kepada yang berpendapat demikian (Taimiyyah, n.d.)"'".

Senada dengan Ibn Taimiyyah, Ibn Qayyim al-Jauziyah juga memaparkan kaidah mengenai prinsip kebolehan dalam muamalah sebagai berikut: 
"Pada prinsipnya hukum akad dan transaksi muamalah adalah sah sampai adanya dalil yang membatalkan dan mengharamkannya" (Ibn Qayyim, 1991).

Pada prinsipnya, multi akad itu dibolehkan dalam fikih Islam apabila memenuhi syarat-syaratnya karena beberapa alasan: pertama, tidak ada dalil yang melarang 'uqûd mustahdatsah (akad-akad baru, salah satunya multi akad); kedua, maqâshid (tujuan) disyariatkannya akad-akad tersebut adalah memperjelas hak dan kewajiban para pihak dalam akad, sehingga setiap pihak mendapatkan haknya tanpa dizalimi; ketiga, mayoritas (jumhur) ulama menegaskan bahwa jika setiap unsur akad yang ada dalam multi akad itu hukumnya sah, maka gabungan akad tersebut itu sah juga (qiyâs al-majmû' 'alâ ahâadiha) (Oni Sahroni dan M. Hasanuddin, 2016).

Berdasarkan ketiga syarat di atas, penulis berpendapat bahwa akad-akad yang terdapat dalam SBSN Sale and Lease Back terpenuhi, terutama syarat ketiga, yaitu apabila setiap unsur akad yang ada dalam multi akad hukumnya sah maka gabungan akad tersebut itu sah juga. Dalam SBSN Sale and Lease Back dalam Fatwa DSN-MUI tidak melanggar kaidah dalam multi akad, karena semua unsur akad di dalamnya terpenuhi baik akad jual-beli maupun akad sewa-menyewa nya.

Pendapat yang menyatakan bahwa tidak semua multi akad adalah diperbolehkan seperti halnya Menikahi seorang wanita hukumnya adalah mubah, akan tetapi apabila seorang laki-laki menggabungkan untuk menikahi seorang wanita dengan saudari wanitanya maka gabungan dua akad nikah ini menjadi tidak boleh.

Menurut penulis, contoh analogi di atas kurang tepat, karena prinsip antara transaksi muamalah dengan munâkahât (hukum perkawinan) adalah berbeda. Perbedaan tersebut terlihat dalam prinsip masing-masing, apabila dalam transaksi muamalah sebagaimana dijelaskan di atas bahwasannya pada prinsipnya adalah dihukumi boleh dan sah, akan tetapi dalam hukum perkawinan hukum asalnya adalah dilarang. Hal ini sebagaimana kaidah berikut:

"Hukum asal pada masalah seks adalah haram"

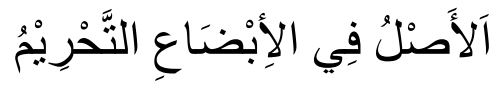

Senada dengan kaidah di atas, al-Syathibi pun membuat kaidah sebagai berikut:

"Hukum asal dalam masalah seks adalah terlarang".

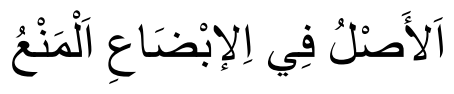


Kaidah ini memiliki makna bahwa dalam hal hubungan seks, pada asalnya haram sampai datang sebab-sebab yang jelas dan tanpa meragukan lagi yang menghalalkannya, yaitu dengan adanya akad perikahan (A. Djazuli, 2016).

Pendapat yang menyatakan bahwa, praktik SBSN Sale and Lease Back dalam Fatwa DSN-MUI adalah praktik multi akad yang dilarang karena termasuk bai' al-wafâ yang dilarang oleh mayoritas ulama. Akan tetapi, hukum mengenai jual-beli wafấ' merupakan perkara yang masih di-ikhtilâf-kan oleh para ulama fikih.

Dalam mazhab Hanafi, akad jual-beli wafâ meruapakah akad jual-beli yang diperbolehkan sebagaimana pernyataan sebagai berikut:

"Disebut menyerupai akad jual-beli yang sah karena setelah akad jual-beli ini berlangsung, pihak pembeli memmiliki hak memanfaatkan barang yang ia beli, sebagaimana dalam akad-jual beli yang sah

Sekalipun dalam akad jual-beli barang yang dijual tersebut harus dijual kembali kepada penjual, namun pembeliannya juga melalui akad jual beli. Ini adalah pendapat yang dipegang oleh generasi mutaakhirin dari mazhab Hanafi. Adapun mengenai syarat yang disebutkan diluar akad, para ulama Hanafi mengatakan bahwa hal tersebut tidak berimplikasi pada pembatalan akad.

Dalam kitab al-Mausû'ah al-Fiqhiyyah al-Kuwaitiyyah dijelaskan bahwa di antara ulama Syafi'iyyah muta'akhirin sebagaimana dijelaskan dalam kitab Bughyah al-Mustarsyidîn membolehkan jual-beli 'udah (nama lain dari jual-beli wafâ) karena akad jual-beli ini dipraktikan dan sudah menjadi 'urf (kebiasaan) serta adanya hâjjah (kebutuhan) untuk menghindari transaksi ribawi. Adapun akad jual-beli wafâ ini menyalahi ketentuan atau kaidah umum, maka akad jualbeli wafâ dinyatakan sebagai hukum pengecualian, sebagaimana akad jual-beli salam (Kementerian Wakaf dan Persoalan Islam Kuwait, 1427).

Berkaitan dengan pendapat yang menyatakan bahwa SBSN/Sukuk Sale and Lease Back dalam Fatwa DSN-MUI sama dengan Sukuk Bahrain (yang menurut sebagian pendapat adalah terlarang) sehingga hukum SBSN Sale and Lease Back dalam Fatwa DSN-MUI tidak jauh berbeda. Penulis berpendapat bahwa, persoalan Sukuk Barharin bahwa tidak semua pakar mengharamkan transaksi tersebut. Hal ini dapat terlihat dalam kitab al-Shukûk: Ahkâuha wa Dhawûbithuha wa Isykâlâtuha karya Fahd Badi al-Mursyidi bahwa ulama fikih kontemporer berbeda pendapat mengenai hukum Sukuk Bahrain. Selain pendapat yang melarang seperti Dr. Nazih Hammad dan Dr. Shadiq al-Dharir, terdapat pula ulama yang membolehkan sukuk Ijarah di Bahrain sebagai berikut:

"Pendapat yang membolehkan sukuk ijarah adalah Fawa 'A'dha alLajnah al-Syar'iyyah sebagaimana fatwa Lajnah al-Riqabah al-Syar'iyyah 
li al-Bank al-'Arabi al-Islami al-Dauli (Panita Pengawas Syariah Bank Arabi Islami Internasional) membolehkan sukuk Bahrain" (Al-Mursyidi, 2014).

Hukum menggabungkan beberapa akad dalam satu transaksi atau hukum multi akad, Dr. 'Aludin al-Za'tari dalam kitabnya Figh al-Mu'âmalât alMâliyyah al-Muqâran: Shiyâgah Jadîdah wa Amtsilah Mu'âhirah, berpendapat bahwa:

“Tidak ada larangan secara syariat mengenai penggabungan dua akad dalam satu transaksi, baik penggabungan itu masuk dalam domain akad pertukaran (mu'âwadhâh) atau akad sosial (tabarru'ât). Hal ini berdasarkan keumuman dalil-dalil yang memerintahkan untuk menunaikan akad dan syarat-syaratnya" (Al-Za'tari, 2010).

Dengan demikian, praktik multi akad dalam SBSN/Sukuk Ijarah Sale and Lease Back dalam Fatwa DSN-MUI yang menggabungkan antara akad jual-beli (bai'), sewa-menyewa (ijârah) dan janji ( $\left.w a^{\prime} a d\right)$ merupakan multi akad yang diperbolehkan secara syariah. Wahbah al-Zuhaili menginfomasikan bahwa, ulama dari kalangan Malikiyyah, Hanabilah dan Syafi' iyyah berpendapat bahwa hukum menggabungkan antara akad jual-beli (bai') dan akad sewa-menyewa (ijârah) diperbolehkan secara hukum (Wahbah al-Zuhaili, 2002).

Dalam teori al-'uqûd al-murakkabah (multi akad) sebaiknya harus ditentukan akad utama dan akad sertaan (tabi'iyyah). Dalam perjanjian sale and lease back terdapat dua perjanjian, yaitu perjanjian jual-beli (sale/bai') dan perjanjian sewa (lease/ijârah atau IMBT). Diduga kuat atau patut diduga kuat bahwa akad yang utama dalam perjanjian sale and lease back adalah perjanjian sewa atau IMBT. Oleh karena itu, dalam hal terjadi akad sale and lease back sebaiknya nomenklatur perjanjiannya adalah perjanjian sewa atau perjanjian IMBT (sesuai kesepakatan). Adapun proses jual-beli boleh diinformasikan pada bagian racitals akta perjanjian karena akad jual-beli (sale) merupakan akad sertaan yang menuntukan boleh-tidaknya aset dijadikan obejk IMBT. Oleh karena itu, pokok-pokok perjanjiannya sama dengan pokok-pokok perjanjian ijârah atau pokok-pokok perjanjian IMBT (Hasanuddin, 2015). 


\section{SIMPULAN}

Konsep sale and lease back dalam kajian fikih muamalah kontemporer disebut dengan istilah al-bai' wa al-isti'jar (al-bai' tsuma al-isti'jar). DSN-MUI telah mengeluarkan fatwa No. 72 Tahun 2008 tentang SBSN Ijarah Salse and Lease Back. Substansi fatwa tersebut pada prinsipnya merupakan keputusan yang dilakukan setelah mempertimbangkan terlanggar-tidaknya kriteria (dhawâbith) multi akad (al-'uqûd al-murakkabah), dimana antara akad jual-beli (bai') dan akad sewa (ijârah) harus dilaksanakan secara terpisah serta dibolehkannya janji (wa'ad) dari pembeli untuk menjual kembali aset yang telah dijualnya kepada penjual. Dengan demikian, konsep multi akad dalam Fatwa DSN-MUI No. 72 tentang SBSN Ijarah Salse and Lease Back merupakan multi akad yang diperbolehkan karena tidak melanggar kaidah serta batasan multi akad yang dilarang syaria

\section{DAFTAR PUSTAKA}

A. Djazuli. (2016). Kaidah-Kaidah Fikih: Kaidah-Kaidah Hukum Islam dalam Menyelesaikan Masalah-Masalah yang Praktis. Prenada Media Group.

Abdalloh, I. (2018). Pasar Modal Syariah. PT Elex Media Komputindo.

Al-Aidi, A. I. H. (2012). Figh al-Aulawiyah Fi al-Mu'amalat al-Maliyyah al-Mu'ashirah. Dar Kunuz Isyibilya.

Al-Mursyidi, F. B. (2014). al-Shukû k: Ahkâuha wa Dhawû bithuha wa Isykâlâtuha. Dar Kunuz Isybilya.

Al-Za'tari, 'Aludin. (2010). Fiqh al-Mu'âmalât al-Mâliyyah al-Muqâran: Shiyâgah Jadî dah wa Amtsilah Mu'âhirah. Dar al-'Asha.

Anonimous. (n.d.). Majallat al-Ahkâm al-Adliyah. Nur Muhammad.

Burhanuddin. (2011). Hukum Surat Berharga Syariah Negara dan Pengaturannya. RajaGrafindo Persada.

Enang Hidayat. (2016). Transaksi Ekonomi Syariah. Rosdakarya.

Eri Hariyanto. (2017). Mengenal Sukuk Negara: Instrumen Pembiayaan APBN Dan Sarana Investasi Masyarakat. Penerbit Gava Media.

Erwandi Tarmizi. (2020). Harta Haram Muamalat Kontemporer. PT Berkat Muliainsani.

Fakhrunnas, F. (2019). Investasi Keuangan Syariah. Ekonisia.

Fathoni, A. I. (2018). Hybrid Contract Pada Lembaga Keuangan Syariah Perspektif Maqā̄idus Syariah. Jurnal Wasathiyah, 2(1), 87. 
Fuady, M. (2002). NHukum tetang Pembiayaan dalam Teori dan Praktiko Title. Citra Aditya Bakti.

Hasanuddin, J. M. dan. (2015). Fikih Mu'amalah Maliyah: Akad Ijarah dan Ju'alah. Simbiosa Rekatama Media.

Ibn Qayyim. (1991). I'lâm al-Muwaqqi'î n 'An Rabb al-'Âlamîn. Dar al-Kutub al'Ilmiyyah.

Jaih Mubarok dan Hasanudin. (2017). Fikih Mu'amalah Maliyyah: Akad Jual-Beli. Simbiosa.

Kementerian Wakaf dan Persoalan Islam Kuwait. (1427). Mausû 'ah al-Fiqhiyyah alKuwaitiyyah. Dar al-Salasil.

Manzhur, I. (2013). Lisân al-'Arab. Dar al-Shadir.

Maulana, H. (2011). Multiakad Dalam Transaksi Syariah Kontemporer Pada Lembaga Keuangan Syariah Di Indonesia,. Al-Iqtishad, 3(1), 172-175.

Melati Anjaswati, Rohimah, T. S. dan R. A. (2016). Tinjauan Fiqih Terhadap Pelaksanaan Sukuk Negara Ijarah Sale And Lease Back Di Pasar Modal Syariah Indonesia. Jurnal Fiqih Transaksi Keuangan Kontemporer, 1(1), 22.

Mingka, A. (2014). Reaktualisasi dan Kontekstualisasi Fikih Muamalah keIndonesiaaan: Upaya Inovasi Produk Perbankan dan Keuangan Syariah. Iqtishad Consulting.

Musthafa Ahmad al-Zarqa. (1999). al-'Uqû d al-Musammah fî al-Fiqh al-Islâmî : 'Aqd al-Baî .' Dar al-Qalam.

Oni Sahroni dan M. Hasanuddin. (2016). Fikih Muamalah: Dinaika Teori Akad dan Implementasinya dalam Ekonomi Syariah. RajaGrafindo Persada.

Rafiq Yunus al-Mishri. (2009). Buhû ts fî Figh al-Mu'âmalât al-Mâliyyah. Dar alMaktabi.

Sri Sudiarti. (2016). Bay' Al-Wafa': Permasalahan Dan Solusi Dalam Implementasinya. Analytica Islamica, 5(1), 184-185.

Suhardi. (2019). Bai' Al-Wafa' Studi Komparatif Antara Ulama Hanafiyah Dan Ulama Syafi'iyah Serta Implemetasinya Di Indonesia. Ensiklopedia Of Journal, 2(1), 118.

Taimiyyah, I. (n.d.). al-Qawấ'id al-Nû râniyyah al-Fiqhiyyah. Dar Ibn al-Jauzi.

Thalib 'Umar Ahmad al-Katsiri. (2015). Nadzariyyah al-Badâil al-Islâmiyyah Lilmu'âmalât al-Mashrifiyyah: Dirâsah Ta'shî liyyah Naqdiyyah. Dar Kunuz Isybilya.

Ubaidillah \& Nawawi. (2017). Tinjauan Istihsan Terhadap Bai' Al-Wafa' Dan Implikasi Konsistensi Bermadzhab Di Baitul Maal Wa Tamwil Sidogiri Cabang Bondowoso. Istidlal, 1(2), 115. 
LAA MAISYIR, Volume 7, Nomor 2, Desember 2020: 277-294

Wahbah al-Zuhaili. (2002). al-Mu'âmalât al-Mâliyyah al-Mu'âshirah. Dar al-Fikr alMu'ashir.

Wahid, N. (2019). Multi Akad dalam Lembaga Keuangan Syariah. Penerbit Deepublish.

Wahid, N. A. (2017). Sukuk: Memahami dan Membedah Obligasi Pada Perbankan Syariah. Ar-Ruz Madia.

Yanti, N. (2017). Ba'i Al-Wafa:Kajian Ekonomi Islam Modern. A-Tanmiyah: Jurnal Ekonomi Dan Bisnis Islam, 1(1), 51. 